\title{
Analysis on the Tax Court Decision on the Deductibility and Arm's Length Price of Royalty Payment (Case Study of PT A and PT B)
}

\author{
Nurfasti Dwi Nugraheni ${ }^{1 *}$, Christine Tjen ${ }^{1}$ \\ ${ }^{1}$ Faculty of Economics and Business, Universitas Indonesia, Depok 16424, Indonesia \\ ${ }^{*}$ Corresponding Author: nurfasti.nugraheni@gmail.com
}

\begin{abstract}
This study aims to understand the underlying considerations of the tax court decisions on PT A and PT B related to identifying the existence and validity of royalty payments for technology (know-how) and trademarks, to assess the conformity of those decisions to the arm's length principle in the Organization for Economic Co-operation and Development (OECD) Transfer Pricing Guidelines, and to determine whether the distribution company could treat royalty payments for technology (know-how) and trademarks as deductible expenses. This research used a qualitative approach with a descriptive research type. The results of this study concluded that the differences in the tax court's decision on PT A and PT B, related to royalty payments for technology (know-how) and trademarks is due to (1) the results of identifying the existence and validity of royalty payments through examining legal agreements, (2) proof of the substance and economic benefits of utilizing intangible property, and (3) proof that there is no double taxation imposed on the payment of compensation for utilizing intangible property. The implementation procedures for the arm's length principle were also made in accordance with the OECD Transfer Pricing Guidelines in order to resolve transfer-pricing disputes.
\end{abstract}

Keywords: Transfer Pricing; Intangible Asset; Tax Court Decision; Royalty; Arm‘s Length Principle.

\section{INTRODUCTION}

Since the role of taxes is to finance the development of a country, in order to maximize revenues from tax, the government must be able to accommodate the economic conditions into tax regulations, which are globally showing an increase in cross borderless transactions. The transition to a global corporate model with central management at regional or international levels has provided opportunities for affiliate and international transactions that result in transfer-pricing mechanism.

Transfer pricing itself is defined as a special selling price used in interdivisional transactions to record the selling division and buying division ${ }^{1}$. However, in its development, transfer pricing refers to the pricing policy used in order to avoid government control and/or activity to utilize the different intergovernmental regulations, with respect to the tax rates ${ }^{2}$.

Utilizing intangible property is one of the issues that often invites debate on transfer pricing, both in terms of theoretical perspectives, and in recognition and assessment. To address this issue, the Organization for Economic Co-operation and Development (OECD) has developed special guidance on intangible property in its Transfer Pricing Guidelines.

Investment in intangible property is very important for multinational companies to further strengthen their position in international market competition. The intangible property itself is generated through a process of research and development (R\&D), which is not easy, often takes a very long time, and does not provide assurance that the process will be able to produce an intangible asset that can raise the value and profitability of the company. It is appropriate that the owner of the intangible property treats it as a company secret, so that if there is any other party that wishes to exploit such an intangible property, the company will have the right to obtain compensation for such utilization. One of the most common forms of compensation is in the form of royalty payments.

In Indonesia, the authority to examine the application of the arm's length principle on related party transactions is held by the Directorate General of Taxation (DGT) as stated in Article 18 Paragraph (3) of Income Tax Law, including the transfer and/or utilization of intangible property. The DGT also has made domestic laws relating to transfer pricing, which states that, in the event of a tax audit being conducted on a transfer-pricing transaction, the DGT must assess the existence and validity of the transaction to determine whether the transaction complies with the arm's length principle or not. However, in practice, the tax authority often did not conduct such a procedure. This results in the resolution of transfer-pricing disputes in Indonesia being difficult and requires a long process. 
The problem arises when there is a discrepancy between a taxpayer and the tax authority with regards to proving the existence and validity of a royalty payment, which results in a dispute over the deductibility and arm's length price of a royalty payment.

The author has identified tax court decisions regarding the royalty-payment disputes for further study/discussion, as follows:

1. Tax Court Verdict No. Put. 41872/PP/M.VIII/15/2012 for PT A, which had a disputed amount of Rp 21,983,600,536 rejected by the tax court.

2. Tax Court Verdict No. Put. 45949/PP/M.III/15/2013 for PT B, which had a disputed amount of Rp $5,280,049,610$ accepted by the tax court.

In order to explore this further, the following research questions will be addressed: (1) what are the underlying considerations of tax court decisions with regard to identifying the existence and validity of royalty payments for technology (know-how) and trademarks, (2) how do the tax court decisions conform to the arm's length principle in the OECD Transfer Pricing Guidelines, and (3) can the distribution company treat the royalty payment as a deductible expense.

This research consists of case studies that refer to two tax court decisions, so there is no similar research. However, there are several other studies that discuss tax disputes for the issue of transfer pricing for intangible property, especially royalty transactions. The differences between this research and previous research are that, in this research, the author will focus the research on royalty payments for know-how and trademarks only, which are charged to the distribution company.

This paper is organized as follows. In section 2, the research method is presented. The discussion results for the analysis of the tax court decisions proposed in this paper are presented in section 3 . Finally, the research in this paper is summarized in the last section.

\section{RESEARCH METHOD}

This research is limited to analyzing two tax court decisions related to royalty-payment disputes on technology and trademarks; i.e., No. Put.41872/PP/M.VIII/15/2012 and No. Put. 45949/PP/M.III/15/2013.

This research used a qualitative approach with a descriptive research type, and was conducted by analyzing the tax court decisions, interviews, and library research. Under this research, the information gathered from the key informants is deemed to be a reliable benchmark that may be used in order to deepen understanding of transferpricing disputes in Indonesia. In this research, the interviews are divided into three different sets: transfer-pricing consultants, academics, and tax officers. This was to gain different perspectives on transfer-pricing practices from both taxpayers and tax authorities.

\section{DISCUSSIONS \\ Dispute Overview \\ Tax Court Decision No. Put. 41872/PP/M.VIII/15/2012 - PT A (Corporate income tax for the year 2007)}

The tax authority presumed that royalty and know-how expenses paid to A France are dividends to the parent company, and there is no utilization of intangible property. The tax court argued that the appellant was not able to prove the existence of the utilization of know-how and trademarks, the existence of training provided, or the economic benefits of the intangible property. The panel of judges decided to maintain the correction because there is no evidence of the use of technology or the use of trademarks. Thus, the royalty fees arising from the use of intangible assets for technology and licensed trademarks could not be treated as deductible expenses in calculating taxable income.

\section{Tax Court Decision No. Put. 45949/PP/M.III/15/2013 - PT B (Corporate income tax for the year 2008)}

PT B is a company whose business activities focus on the trade of apparel products. The dispute is a fiscal correction for a royalty payment to B BV in the Netherlands. The tax auditor contended that the taxpayer is not entitled to claim royalty expenses because of a lack of documents being provided to allow the analysis of the affiliate transaction, but during the tax-audit process the appellant submitted the global transfer-pricing documentation, agreement, and payment as references to be used to determine the existence and validity of the transaction. The judges applied several criteria to ensure that the royalty fees are at arm's length; i.e., with respect to their existence, benefits, duplication, and valuation. The appellant argued that the existence and benefits of the royalty payment are shown by the trademark registration for intellectual property rights (Hak atas Kekayaan Intelektual) (HAKI), agreement B BV with an independent party, and the increase in sales/profit. The appellant assured the tax office that there was no duplication on royalty expenses, which was proven by submitting a statement letter from the Netherlands Tax Office, and an independent auditor of BV stated that the royalty income was taxable in the Netherlands. For the valuation, PT B had prepared documentation and research to calculate the 
arm's length price for royalty, i.e. 4\% of net sales. The license agreement was signed in 2006 between B BV and the appellant. The appellant won the case.

\section{Analysis of the Consideration of the Tax Court Decision Related to Identifying the Existence and Transfer of Intangible-Property Utilization \\ The Legal Basis of the Dispute}

The correction was conducted based on Article 18 Paragraph (3) of Law No. 17 of year 2000; using this article once the transactions could be proved by the related parties, the tax authority disregarded the expenses or revenues. The purpose of this provision is to prevent tax avoidance; thus, it is an important to determine the existence of a tax-avoidance motive by using the difference in rates between countries that have higher tax rates and countries with lower tax rates. Based on this, in the dispute of PT A, the tax rate of the country of destination for the royalty payment is greater than the prevailing tax rate in Indonesia. Therefore, using the difference in tax rates does not prove there was a motive of tax evasion. Whereas, in the PT B dispute, the tax rate of the domicile of the affiliated party was less than the prevailing tax rate in Indonesia, so it is possible there was a tax-avoidance motive. However, the transactions conducted by PT B with the affiliate are not necessarily considered to be a form of tax avoidance.

\section{Ownership Structure}

Corrections made based on Article 18 Paragraph (3) of the Income Tax Law may only be used if there is a "special relationship" between the parties conducting the transaction. Without a "special relationship," the transaction is assumed to be settled under fair market mechanisms, resulting in a reasonable taxable income. Referring to the court decision, it is known that the two appellants (i.e., PT A and PT B) are foreign investment companies in which all of their shares are owned by their group companies. Therefore, regarding the correction based on Article 18 Paragraph (3) of the Income Tax Law, in redetermining the fairness value of the transaction, it should be assessed what the applicable taxation provisions are.

\section{Characteristics and Business Functions}

Based on the data, the researcher concludes that two appellants have the characteristics and business functions of distributors. This research concludes the following. Firstly, regarding the products marketed, the appellant is not responsible for the strategy and product design. Secondly, the appellants are granted the right to use intangible property (technology and trademarks), and granted exclusive rights in connection with the distribution and marketing of licensed products. This shows that both PT A and PT B are not the owners of the intangible property. Thirdly, the appellants are responsible for and have their own authority over the functions of marketing, distribution, logistics, and procurement in the territory of Indonesia, and bear the risk of the functions.

\section{Transaction Scheme and Terms of Agreement}

The transaction scheme conducted by PT B is not much different from the transaction scheme used by PT A. The difference between PT A's and PT B's transaction schemes is the determination of the party manufacturing the licensed product. In this case, PT A appointed the affiliated party in A group as the manufacturing company, while PT B appointed an independent party as the company that produced the licensed products.

\section{Explanation of the Substance and Economic Benefits of Affiliate Transactions}

In the process of settling disputes over transactions that are affected by an associated relationship involving the use of intangible assets, the fairness of such transactions will be determined in accordance with the procedures under applicable regulations; this is done by conducting a comparison analysis to produce comparable transactions in which one of the test procedures is proven to be related to the substance and economic benefits received. In this case, the lack of explanation accompanied by insufficient supporting evidence of the dispute resolution for PT A compared to the explanation and evidence submitted by PT B during the trial indicates that the panel of judges considered procedural aspects in applying the arm's length principle to resolve the dispute related to transfer pricing.

\section{Proof during a Tax Hearing}

Under the conditions of a dispute related to transactions conducted with affiliates that has been assessed and reasonably tested in accordance with the procedures under applicable taxation provisions, the panel of judges will emphasize the proof of the transaction's substance, the truth, and the economic and commercial benefits of the transaction. This can change the result of the verdict. The court's ruling on the PT B dispute is an example where the judge's conviction was influenced by the evidence during the trial. However, in the dispute-resolution process 
for PT A, a lack of sufficient evidence resulted in the rejection of the appeal. From both decisions it appears that the burden to prove the material truth of the fairness of the royalty payments was borne by the appellant. In the dispute resolution for PT A, the evidence is made up not only of the formal and material truth of the royalty-payment transaction, but also of the proof of the substance of the transaction and the economic benefits received by the appellant. In addition, proof was also submitted on the absence of a double deduction against the royalty fee charged.

\section{Analysis of the Conformity of the Tax Court Decision to the Arm's Length Principle According to the OECD Transfer Pricing Guidelines Identifying the Existence of Intangible-Property Utilization}

Referring to paragraph 38 of the OECD Discussion Draft, the intangible-property utilization can be assessed by identifying its existence, ownership, and transaction scheme. The existence of intangible-property utilization can be proven by using the license agreement and comparing it with the operational facts that occur in the field. In the dispute of PT A, the provision in the agreements is not really in accordance with the operational facts. The appellant appointed another manufacturing company to undertake the production of the licensed product. This is inconsistent with the provisions, which state that the license must be used by the appellant and cannot diverted to other party. Although it is possible that, in practice, the utilization of the intangible property is valid, but the inconsistency of the contents of the agreement with the factual operations means this transaction is irregular.

The difference in the context for determining the definition of a royalty occurred in the dispute-resolution process of PT B. The existence and delivery of intangible property (royalties) in PT B's dispute is proved by the submission of the proof of registration of intangible property to the director general of HAKI, the license agreement between B IMBV and the appellant, and the as license agreement between B IMBV and the other parties that are similar to the appellant.

Furthermore, the author's concern in this identification process is with the ownership of the intangible property. Based on the copy of the court decision, it is known that B IMBV gave the license right over the intangible property through a license agreement, and the owner of the intangible property is B AG as evidenced by the HAKI registration. This is inconsistent when the license agreement is not made by the legal owner of the intangible property itself. The ownership of intangible property cannot necessarily be determined through legal forms. It should also be considered that B IMBV may have become the owner of the intangible property through a cooperation agreement or an understanding that B IMBV is one of the parties that will bear the costs and risks on the development of intangible property. It will not be easy to find proof of this because of the limitations of the data, as the object of the research is only the court decision, and in the court decision itself does not further discuss the ownership of intangible property.

\section{Assessment of the Transfer/Utilization and Economic Benefits of Royalty Payments}

In the concept of transfer pricing, transactions with affiliates will be considered to be fair if an independent company can also do the same. Thus, the existence of an independent company willing to pay a similar royalty is one of the strong foundations for proving the feasibility of royalty payments. The assessment of the economic benefits of utilizing intangible property can be seen from improvements in the operational and financial performance of a company. In PT A's dispute, the appellant has explained that they have received economic benefits from utilizing the intangible property, but cannot submit strong evidence relating to the authentication and economic benefits of such royalty payments. On the other hand, the author does not find any procedures implemented to determine the arm's length price, as suggested in the OECD Transfer Pricing Guidelines.

In contrast, in the trial for PT B's dispute, the researcher found that the appellant has applied the arm's length principle to an affiliate transaction. The validity of utilizing intangible property is provided through documentary evidence in the form of payment proof, the royalty agreement between B IMBV and a third party, and a letter of apology from Mr. MR regarding using a licensed product mark without the permission. The appellant also submitted an explanation regarding the economic benefit received through an increase in sales. The feasibility of royalty payments can also be tested by determining whether other companies are willing to pay similar royalties. In the case of PT B, this can be proved by the existence of the IMBV B license agreement with independent parties.

\section{Determining the Arm's Length Price of a Royalty Payment}

The arm's length valuation of intangible-property transactions is done after obtaining an understanding of the existence and validity transfer/utilization of the transaction itself, through a function and comparison analysis. In the dispute of PT A, the appellant stated that the amount of royalty paid is 5\%-6\% for the formula, and $1 \%$ for the trademark. In addition, the appellant also submitted comparable data showing that similar companies also pay a large amount of royalties to the head office. However, the explanation is not supported by the function and 
comparable analysis, so that argument is not reliable.

Considering that the obligation for the Indonesian taxpayer to prepare transfer-pricing documentation started on September 6, 2010 through PER-43/PJ/2010, therefore, in fiscal year 2007, there was no obligation to submit transfer-pricing documentation. However, the appellant or appellee could prepare a transfer-pricing analysis to assess the arm's length price of the royalty payment. In the dispute resolution of PT B, the assessment of the arm's length price of the royalty payment was submitted and proven by the appellant, which is shown on the local transfer-pricing documentation and the global transfer-pricing documentation.

\section{Deductibility of Royalty Payments for Technology (Know-How) and Trademarks for Distribution Companies}

Based on the understanding related to the concept of the distribution company and the interview results, the author concludes that a distribution company can impose royalties on know-how and trademarks. The basis of such a conclusion is the facts regarding the characteristics and functions of the business of the distribution company, where, generally, the distribution company is granted a license to use the intangible property, and an exclusive right to market, sell, and distribute licensed products by the principal. By obtaining a license for a trademark and knowhow, the distribution company gets additional value from the technology and technical know-how attached to the product; this affects the quality of a marketed product, which is the customer's primary judgment in deciding whether to buy a product or not.

In addition, the licensed brand is usually a brand that has a high value, some are even already known at the world level. This allows distributors to enter into the domestic market and conduct marketing activities that are appropriate to intended market. The use of brands and distribution rights can also provide benefits in the form of revenue from the sale of licensed products, which will provide higher returns. In the event that the licensed trademark has no value, then the distribution company will not get the benefits and advantages from the use of the trademark. However, this does not necessarily reduce the functions and risks to be borne by the distribution company. Distribution companies continue to perform strategic and operational functions, and bear risks for products, markets, and failing to collect. Therefore, it can be said that the distribution company retains an interest in the product, and benefits from the use of the trademark and know-how.

\section{CONCLUSION}

From the results of this study it can be concluded that the difference in the tax court decisions on PT A and PT B, related to royalty payments for technology (know-how) and trademarks is due to the following: (1) the results of identifying the existence and validity of royalty payments through examining legal agreements and their conformity with the taxpayer's actual operations; (2) the proof and explanation of the substance and economic benefits of utilizing intangible property, as stated in Chapter VI of the OECD Transfer Pricing Guidelines, plays an important role in considering a decision; and (3) the proof that there is no double taxation imposed on the payment of compensation for utilizing intangible property in the domicile country is one of the factors that supports the consideration of a decision.

Furthermore, it can be concluded that, during the tax hearing, the panel of judges conducted the procedure to determine the arm's length price of the royalty payment for utilizing intangible property, which is in accordance with the OECD Transfer Pricing Guidelines. However, the panel of judges did not analyze the comparability or the selection of the transfer-pricing method, since that is the DGT's authority, and the panel can only judge the evidence and documents that support the arguments of both sides.

Basically, the distribution company could treat the royalty payments for know-how and trademarks as deductible expenses because the distribution company has an interest in the licensed products, which it markets, and from which it gains economic benefits from the use of intangible property. However, the deductibility and arm's length price of the royalty payment must be in accordance with the agreement, and the function, risk, and operational business of the company.

This research still has some limitations; i.e., it only analyzed specific disputes during fiscal year 2007-2008, and was only based on the applicable Indonesian tax regulations. Therefore, the results of this research may only apply in Indonesia because the objects of research itself are the decisions of the tax court of Indonesia. This research also focuses only on the facts and data written in the court decision, so that the analysis result can be accounted for.

It is advisable that, during the tax-audit process, the DGT must fully implement procedural aspects to assess the related party's transactions. In the case of an appeal dispute, the corrections made by the DGT can be maintained during the hearing. Furthermore, if the taxpayer has a transaction with a related party, it should support the documentation of the fairness and business results of an affiliate transaction (transfer-pricing document), and agree with other supporting documents that can explain the substance and benefits of the transaction. Hence, in the event of a dispute, the documentation can be shown to support the documents and evidence used in the process of 
determining the reasonableness of the price.

\section{REFERENCES}

[1] H Simamora. Akuntansi Manajemen. Salemba Empat, Jakarta (1999).

[2] L Eden. The Internalization Benefits of Transfer Price Manipulation. Working Paper, The Bush School of Government \& Public Service Texas A\&M University (2003). 